${ }^{4}$ HILLMAN, W. S. 1959. Experimental control of flowering in Lemna I. General methods. Photoperiodism in L. perpusilla 6746. Amer. Jour. Bot. 46: 466473.

${ }^{5}$ JACOBS, D. L. 1947. An ecological life history of Spirodela polyrhiza with emphasis on the turion phase. Ecol. Mono. 17: 438-469.

${ }^{6}$ MUIR, B. J. 1981. Unpublished. A feasibility study using Lemna minor $L$. in a bioassay for boron phytotoxicity.

${ }^{7}$ FASSETT, N. C. 1966. Manual of Aquatic Plants. Univ. Wisc. Press, Madison.

${ }^{8}$ GLANDON, R. P. and C. D. MCNAB 1978. The uptake of boron by Lemna minor. Aqua. Bot. 4: 53-64.
${ }^{9}$ GUIDE TO AQUATIC NUISANCE CONTROL. Environment Saskatchewan pub. 1978.

${ }^{10}$ STEINBERG, R. O. 1941. Use of Lemna for nutrition studies on green plants. Jour. Agr. Res. 62: 423-430.

"HARPER, J. L. 1961. Approaches to the study of plant competition. In F. L. Milthorpe Ed. Mechanisms in Biological Competition. Symp. Soc. Exp. Bot. 15: 1-39.

${ }^{12}$ HARPER, J. L. 1978. Population Biology of Plants. Acad. Press, London.

${ }^{13}$ LOCKHART, W. L. and A. P. BLOUW 1979. Phytotoxicity tests using the duckweed, Lemna minor. Can. Pub. Fish. Aq. Sci., Gov't. Canada.

\title{
COTTONWOOD: A RARE TREE NEAR THE PAS, MANITOBA
}

\section{WALTER KRIVDA, Box 864 , The Pas, Manitoba. R9A 1 K8}

For a quarter of a century I have been looking for the Cottonwood (Populus deltoides) on my various collecting trips.

I was aware of records further west in Saskatchewan and also of my own record from Riding Mountain National Park - on the highway between the North Gate of the Park and Dauphin. There is also an old report from Vermillion Park in Dauphin and The Flora of Canada identifies this report as the furthest north location in Manitoba for this species. ${ }^{1}$

The first local record of the Cottonwood was in the 1960's when a single tree with many dozens of suckers forming was found. This tree was found on the edge of a farm field, in the then, just opened up Pasquia settlement area about 170 miles north of Dauphin. This clone has since enlarged and is deeply entrenched, is not being disturbed and the crop is planted around it.
The second local record for the Cottonwood was made when plant collections were made on the Carrot River Road between The Pas and the Saskatchewan border, a distance of about 35 miles. Here also a single tree was found along the highway. This is a solitary tree which is not cloning.

This entire local area was heavily flooded in 1948. The water was so deep that only the cross bars on the tops of the telephone poles were visible. If Populus deltoides cannot stand a whole summer's drowning, it may well be that these two trees arrived as seeds after the water subsided, which would make them just short 35 years of age. It would be interesting to take increment borings to discover the actual ages of the trees.

The third and final local record, for the present, of the Cottonwood consists of several trees on the shore of Readers Lake at Wachie Bay a short walk from 
Jedd Readers home. These also appear to be young trees.

In addition I have had reports of big poplar trees down the Saskatchewan River from The Pas, that have "leaves with pinking shears toothing." However these reports are not supported by voucher specimens.

The Reader Lake record is of particular interest because the trees are in pure sand on the edge of the lake. Various sand bars occur eastward from The Pas in the winding Saskatchewan River providing an ideal habitat for this poplar species. If these sand bars were explored botanically and specimens collected I am confident that additional records will be made. The species well may range into the Summer Berry Marshes.

Duplicate herbarium specimens of local Populus deltoides will be sent out in exchanges, to other Canadian and foreign Herbaria this year.

' SCOGGAN, H.J. 1978. The Flora of Canada. National Museums of Canada, Ottawa.

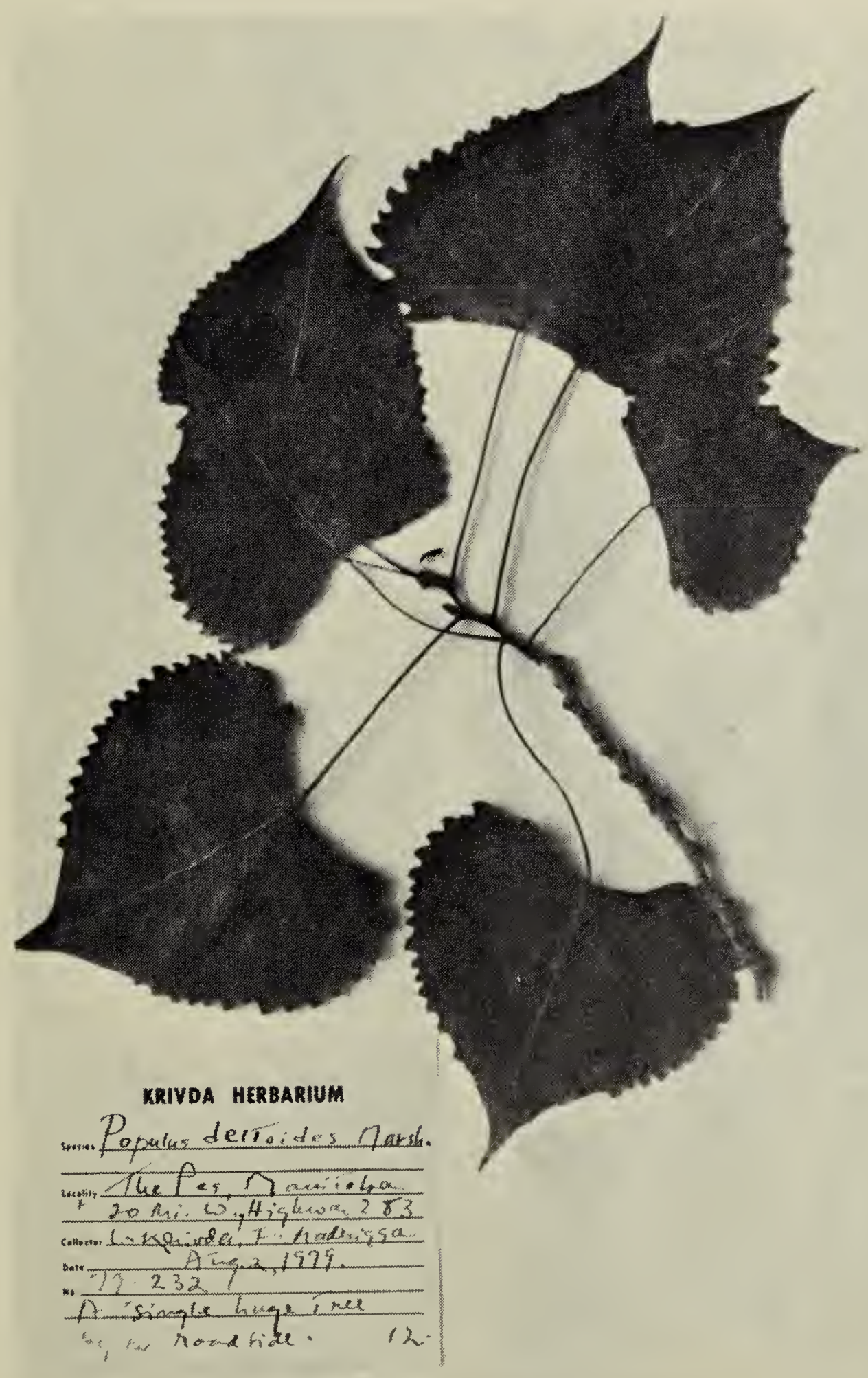

